\title{
Thyroid function in pediatric population with different nutritional status
}

\author{
María R. Ayala-Moreno*, Jennifer Guerrero-Hernández, Arely Vergara-Castañeda, \\ Germán Salazar-Aceves and Diego E. Cruz-Mercado
}

Laboratorio de Obesidad y Enfermedades Metabólicas, Grupo de Investigación en Alimentos y Salud de la Facultad de Ciencias Químicas, Universidad La Salle, Ciudad de México, México

\begin{abstract}
Background: Thyroid dysfunction has been associated with the development of obesity. There are few studies describing their status in Mexican schoolchildren, in whom obesity and subclinical hypothyroidism (SCH) prevail. Methods: Levels of stimulating thyroid hormone (TSH) and thyroid hormones (TH) were correlated with anthropometric variables as indicators of nutritional status in schoolchildren residents of Mexico City. The thyroid status and prevalences of SCH were compared between all the nutritional conditions, considering the degree of pubertal development. Results: The mean of TSH was 2.96 $\pm 1.48 \mathrm{mIU} / \mathrm{L}$, and the prevalence of $\mathrm{SCH}$ was $11.30 \%$. TSH levels are higher in prepubertal $(5.21 \pm 1.24 \mathrm{mIU} / \mathrm{L}$ (95\% confidence interval [CI]: 3.72-6.69) versus pubertal children (2.96 $\pm 1.48 \mathrm{mIU} / \mathrm{L}[95 \% \mathrm{Cl}: 2.61-3.30)$, as well as in children with obesity $(3.5 \pm 1.13 \mathrm{mIU} / \mathrm{L}$ [95\% Cl: 2.98-4.02]) versus normal weight children $(2.43 \pm 1.37 \mathrm{mIU} / \mathrm{L}$ [95\% Cl: $1.88-2.97])$. The $\mathrm{TH}$ is similar in the whole population, although triiodothyronine total levels tend to be lower in malnourished children. There is a positive correlation between TSH levels and all anthropometric variables. The prevalences of SCH were higher in groups of children with overweight and obesity. Conclusions: The body fat content is associated with thyroid status in Mexican schoolchildren. In addition, it is relevant to consider the degree of pubertal development for diagnosing hyperthyrotropinemia in children and adolescents.
\end{abstract}

Key words: Thyroid function. Thyroid hormones. Nutritional status. Subclinical hypothyroidism.

\section{Función tiroidea en población pediátrica con diferente estado nutricional}

\section{Resumen}

Introducción: La disfunción tiroidea se ha asociado con el desarrollo de obesidad. Existen pocos estudios descritos en población escolar mexicana, en quienes prevalece la obesidad y el hipotiroidismo subclínico (HSC). Métodos: Los niveles de hormona estimulante de tiroides (TSH) y hormonas tiroideas (HT) se correlacionaron con variables antropométricas indicadoras del estado nutricional de niños escolares residentes de la Ciudad de México. El estado tiroideo y las prevalencias de HSC se compararon entre todas las condiciones nutricionales, considerando el grado de desarrollo puberal. Resultados: La media de TSH fue $2.96 \pm 1.48 \mathrm{mUI} / \mathrm{L}$, y la prevalencia de HSC fue de $11.30 \%$. Los niveles de TSH fueron

\section{Correspondencia:}

*María del Rosario Ayala-Moreno

Email: rosario.ayala@ulsa.mx
DOI: 10.24875/BMHIM.M18000036

Fecha de recepción: 09-10-2017

Fecha de aceptación: 20-10-2017
Disponible en internet: 25-09-2018 Bol Med Hosp Infant Mex. 2018;75:279-286 www.bmhim.com

1665-1146/@ 2018. Hospital Infantil de México Federico Gómez, impreso por Permanyer México SA de CV, todos los derechos reservados. 
mayores en los niños prepúberes (5.21 $\pm 1.24 \mathrm{mUIIL}$ [intervalo de confianza (IC) 95\%: 3.72-6.69]) vs. los niños púberes (2.96 $\pm 1.48 \mathrm{mUIIL}$ [IC 95\%: 2.61-3.30); así como en los niños con obesidad (3.50 $\pm 1.13 \mathrm{mUIIL} \mathrm{[IC} \mathrm{95 \% :2.98-4.02])} \mathrm{vs.} \mathrm{los} \mathrm{niños}$ con peso normal (2.43 $\pm 1.37 \mathrm{mUIIL}$ [IC 95\%: 1.88-2.97]). Los niveles de HT son similares en toda la población, aunque los niveles de triiodothyronine total $\left(T_{3}\right)$ tienden a ser menores en niños desnutridos. Existe correlación positiva entre los niveles de TSH y todas las variables antropométricas. Las prevalencias de HSC fueron mayores en los grupos de niños con sobrepeso y obesidad. Conclusiones: El contenido de grasa corporal está asociado con el estado tiroideo en escolares mexicanos. Adicionalmente, es relevante considerar el grado de desarrollo puberal para el diagnóstico adecuado de hipertirotropinemia en niños y adolescentes.

Palabras clave: Función tiroidea. Hormonas tiroideas. Estado nutricional. Hipotiroidismo subclínco.

\section{Introduction}

The high prevalence of overweight and obese children in Mexico is a major public health problem, and its association with metabolic diseases has been increasing in young population ${ }^{1,2}$. Evaluating the association between obesity and thyroid dysfunction has been of great interest because thyroid hormones $(\mathrm{TH})$ affect the regulation of energy metabolism and body weight $^{3,4}$. However, studies examining thyroid status in children and adolescents are limited and show inconclusive results. Some studies report that thyroid-stimulating hormone (TSH) levels in obese children and adolescents are slightly higher, but still within the normal range when compared to children of adequate weight for their height and age ${ }^{5-7}$. Other reports in animals have suggested that an increased adiposity promotes a status of hyperthyrotropinemia in which leptin shows the important hypophysiotropic effect of increasing the production of pro-thyrotropin-releasing hormo$\mathrm{ne}^{8}$, although a significant connection between leptin levels and serum TSH has not been reported in all population studies ${ }^{7}$. On the other hand, a higher prevalence of subclinical hypothyroidism $(\mathrm{SCH})$, characterized by high serum TSH levels and normal concentrations of $\mathrm{TH}$, has been described in obese children, with values ranging from $7.5 \%$ to $17 \%$ based on the hyperthyrotropinemia cutpoint ${ }^{5,9}$. According to the report of the National Institute of Public Health (2012), derived from the results of the National Nutrition and Health Survey, the prevalence of hyperthyrotropinemia in Mexico was $10.3 \%$ in pediatric population aged $6-12$ years ${ }^{10}$. Few studies have compared thyroid function variations in children with different nutritional status determined by body mass index (BMI), but only as a secondary objective $\mathrm{e}^{11}$. In addition to nutritional status, other factors that may affect the thyroid status in children (for example, the degree of pubertal development) have not been considered in the studies ${ }^{12}$. In this paper, we aimed to evaluate the correlation between the levels of TSH and TH with the different anthropometric indicators of nutritional status as well as compare the prevalence of $\mathrm{SCH}$ in the different nutritional status, considering the pubertal development level for such diagnostic, in a sample of children from Mexico City.

\section{Methods}

\section{Design and study objects}

A cross-sectional study was conducted in 74 children and adolescents between the ages of 8 and 12 in Mexico City. The sample size was calculated based on the reported SCH prevalence of $10.3 \%$ in Mexican population (INSP) ${ }^{10}$ and expected a correlation between free thyroxine $\left(\mathrm{FT}_{4}\right)$ and $\mathrm{z}-\mathrm{BMI}$, similar to that reported by Brufani et al. $.^{13},(r=-0.23$, which is considered one of the highest reported correlations), resulting in $n=56$ and 76 children, respectively. Both estimations were made considering a $95 \%$ confidence and a power of $80 \%$. The parents or guardians of adolescents and children signed a letter of informed consent and children signed an agreement letter.

For participant recruitment, meetings were held with authorities of the Secretariat of Public Education (SEP, for its Spanish acronym) of Mexico City, who made the direct invitation to different primary schools. Once approved by the corresponding authorities, promotional material (brochures and posters) was used. In addition, invitation letters addressed to parents were sent, and informative meetings were developed with parents to explain the study and clarify doubts.

Biological age based on measurement pubertal development: We considered the biological age of children according to Lopes-Machado and Brabanti ${ }^{14}$, as the age of an individual defined by the processes of biological maturation. This was determined with the assessment of sexual maturity using the Tanner scale, which is based on the observation of secondary sexual characteristics that determine the stages of pubertal development. The 
stages of puberty were indicated by the children, with the support of their parents or tutors, using illustrations that correspond to the Tanner scale. Pubertal development was categorized into five stages for males (based on genital, including penis, scrotum, and pubic hair development) and females (based on breast and pubic hair development). The categories were prepuberty (Tanner I) and puberty (Tanner II to V) ${ }^{15}$.

Anthropometric measurements and determining nutritional status: anthropometric measures, including weight $(\mathrm{kg})$, height $(\mathrm{m})$, and waist circumference (WC, in $\mathrm{cm}$ ), were carried out by trained staff of the Nutrition Area of the Faculty of Chemical Sciences. Waist-toheight ratio $(\mathrm{WHtR})$ and $\mathrm{BMI}$ were calculated by dividing WC $(\mathrm{cm})$ by height $(\mathrm{cm})$ and weight $(\mathrm{kg})$ by height squared $\left(\mathrm{m}^{2}\right)$, respectively. The population was stratified as follows: (A) BMI percentiles for age and gender were identified in CDC tables ${ }^{16}$, and according to Bar${ }{ }^{10}{ }^{17}$, the obesity was defined as $\mathrm{BMI} \geq 95^{\text {th }}$ percentile, overweight as BMI between the $85^{\text {th }}$ and $94.9^{\text {th }}$ percentile, normal weight as BMl between the $5^{\text {th }}$ and $84.9^{\text {th }}$ percentile, and undernutrition as $\mathrm{BMI} \leq 5^{\text {th }}$ percentile; (B) WC percentiles for Mexican population were used to assess the presence or absence of central obesity (WC $\geq 90^{\text {th }}$ percentile) according to gender and age $^{18}$; and (C) WHtR (to indicate presence of obesity; i.e., $\mathrm{WHtR} \geq 0.5)^{19}$.

\section{Determining thyroid status}

Fasting blood samples were obtained $(6 \mathrm{~mL})$ and analyzed to determine the serum levels of $\mathrm{TSH}, \mathrm{T}_{3}$, thyroixine total $\left(\mathrm{T}_{4}\right)$, and $\mathrm{FT}_{4}$ as indicators of thyroid status. Immunoassay (ELISA) kits, Human TSH kit, and TH International Diagnostic Laboratory SC kits were used. All determinations were performed in duplicate considering reliable analysis when the intra-assay coefficient of variation was $<5 \%$.

$\mathrm{SCH}$ diagnosis was established using elevated levels of TSH $(\geq 4.5 \mathrm{mIU} / \mathrm{L} \text { to } \mathrm{TSH}<10 \mathrm{mIU} / \mathrm{L})^{20}$ and normal levels of $\mathrm{TH}$ as criteria ${ }^{21}$.

\section{Statistical analysis}

Statistical analysis was performed using SPSS software version 20.0 (IBM SPSS Statistics, USA). Descriptive characteristics of the study population were tabulated, and Pearson or Spearman correlations were performed to assess the relationship between $\mathrm{TH}$ and BMI, WHtR, and WC. T-student and ANOVA tests, or their corresponding nonparametric tests were used to compare $\mathrm{TH}$ according to gender, biological age, and nutritional status, respectively. Finally, the prevalence of $\mathrm{SCH}$ was compared using a Chi-square test $\left(X^{2}\right)$. A $p<0.05$ was considered statistically significant.

\section{Results}

A total of 74 children were included in this study, 37 of which (52.11\%) were females; according to BMI, the prevalence of obesity was $25.35 \%$, while $32.39 \%$ presented overweight, $33.80 \%$ normal weight, and $8.45 \%$ were classified as undernourished. No differences in weight, height, anthropometric variables, and chronological age were identified between genders, but males were older than females in terms of Tanner scales $(p<0.001)$ (Table 1). However, it is important to emphasize that prepubertal children (Tanner I) presented significantly higher values of TSH than those found in pubertal children $(5.21 \pm 1.24 \mathrm{mIU} / \mathrm{L}$ vs. $2.96 \pm 1.48 \mathrm{mlU} / \mathrm{L}, p=0.004)$. To avoid the influence of puberty on thyroid status, we only considered children of Tanner stages II to $\mathrm{V}$ ( $n=71,95.94 \%$ of the sample), of which $60.74 \%$ were in Tanner II, $28.17 \%$ in Tanner III, and $7.04 \%$ in Tanner IV. Prepubertal children were not considered for the subsequent analysis $(n=3 ; 4.05 \%$ of the sample).

The mean $\mathrm{TSH}$ and $\mathrm{FT}_{4}$ values for pubertal children were $2.96 \pm 1.48 \mathrm{mIU} / \mathrm{L}(95 \% \mathrm{Cl} 2.65-3.26)$ and 16.66 $\pm 2.71 \mathrm{pmol} / \mathrm{L}(95 \% \mathrm{Cl} 16.03-17.29)$, respectively. Median values for $\mathrm{T}_{4}$ and $\mathrm{T}_{3}$ were 74.64 (36.04) $\mathrm{nmol} / \mathrm{L}$ and $2.30(0.84) \mathrm{nmol} / \mathrm{L}$, respectively. TH levels were similar between females and males (Table 2).

The thyroid status of the population stratified according to the nutritional condition is shown in Table 3. Mean TSH was within the normal range in all nutritional conditions, but in the obese group, it was significantly higher when compared to the normal weight group $(p<0.05)$. In addition, overweight children showed similar TSH levels when compared to obese children, although such levels were not significantly different from normal weight subjects. When considering obesity according to WHtR, obese subjects showed higher levels of TSH with respect to non-obesity children $(3.5 \pm 1.35[95 \% \mathrm{Cl} 3.10-3.89]$ vs. $2.75 \pm$ 1.52 [95\% Cl: 2.24-3.25; $p<0.035$ ). Similarly, higher levels $(14 \%, p<0.05)$ were found considering WC, although differences were not significant $(p=0.213$ ). Undernourished and obese children presented similar 
Table 1. Basic characteristics of population.

\begin{tabular}{|c|c|c|c|c|}
\hline Variable & Females & Males & Total & $\mathbf{p}$ \\
\hline Chronological age (years) & $10.16 \pm 1.02$ & $10.03 \pm 1.15$ & $10.07 \pm 1.12$ & 0.62 \\
\hline Tanner scales (years) & $11.86 \pm 0.43$ & 11.74. \pm 0.87 & $11.44 \pm 0.87$ & $0.001^{*}$ \\
\hline Height (m) & $1.41 \pm 0.10$ & $1.37 \pm 0.09$ & $1.39 \pm 0.10$ & 0.08 \\
\hline Weight $(\mathrm{kg})$ & $43.21 \pm 13.06$ & $38.29 \pm 13.53$ & $40.85 \pm 13.42$ & 0.12 \\
\hline Weight z-score & $0.037 \pm 0.18$ & $-0.036 \pm 0.19$ & $0.003 \pm 0.19$ & 0.12 \\
\hline$W C(\mathrm{~cm})$ & $73.00(18.25)$ & $68.10(22.42)$ & $71.20(20.00)$ & 0.42 \\
\hline WC z-score & $0.078 \pm 0.93$ & $-0.083 \pm 1.07$ & $0.006 \pm 1.0$ & 0.49 \\
\hline $\mathrm{BMI}$ & $18.79(7.91)$ & $21.08(7.39)$ & $20.36(7.91)$ & 0.17 \\
\hline BMI z-score & $0.14 \pm 0.99$ & $-0.15 \pm 0.99$ & $0.016 \pm 1.0$ & 0.21 \\
\hline WHtR & $0.51 \pm 0.07$ & $0.51 \pm 0.11$ & $0.51 \pm 0.14$ & 0.87 \\
\hline WHtR z-score & $-0.020 \pm 0.77$ & $0.023 \pm 0.21$ & $0.0008 \pm 1.0$ & 0.85 \\
\hline Prevalence of SCH (\%) & 11.70 (Cl 95\% 10.3-13.10) & 11.00 (CI 95\% 9.9-12.10) & 11.30 (CI 95\% 10.4-12.20) & 0.63 \\
\hline
\end{tabular}

Table 2. Thyroid state stratified by gender.

\begin{tabular}{|l|c|c|c|c|}
\hline Serum levels & Females & Males & Total & $p$ \\
\hline $\mathrm{TSH}(\mathrm{mlU} / \mathrm{L})$ & $3.04 \pm 1.74$ & $2.93 \pm 1.33$ & $2.96 \pm 1.48$ & 0.82 \\
\hline $\mathrm{T}_{4}(\mathrm{nmol} / \mathrm{L})$ & $74.64(46.33)$ & $74.64(56.63)$ & $74.64(36.04)$ & 0.40 \\
\hline $\mathrm{T}_{3}(\mathrm{nmol} / \mathrm{L})$ & $2.34(0.73)$ & $1.99(1.08)$ & $2.30(0.84)$ & 0.63 \\
\hline $\mathrm{FT}_{4}(\mathrm{pmol} / \mathrm{L})$ & $16.66 \pm 2.71$ & $16.57 \pm 3.39$ & $16.66 \pm 2.71$ & 0.97
\end{tabular}

Data are mean \pm SD in data with a normal distribution (TSH and $\mathrm{FT}_{4}$ ) or median (IQR) in data with non-normal distributions ( $\mathrm{T}_{4}$ and $\mathrm{T}_{3}$ ). Levels of TSH and thyroid hormones were compared according to gender using Student's t-test or Wilcoxon test.

TSH: thyroid-stimulating hormone, $\mathrm{FT}_{4}$ : free thyroxine, $\mathrm{T}_{4}$ : thyroxine total, $\mathrm{T}_{3}$ : triiodothyronine total, $\mathrm{SD}$ : standard deviation, IQR: interquartile range

TSH levels, and additionally, $\mathrm{T}_{3}$ levels tend to be lower when compared with normal weight children (0.65 [0.76] vs. $0.93[0.38, p=0.069)$.

Analysis of thyroid status and anthropometric indicators showed a positive correlation between TSH levels and all obesity indicators (weight, BMI, WC, and WHtR) or their respective $z$-score values, whereas $T_{4}, T_{3}$, and $\mathrm{FT}_{4}$ levels were not correlated with any of the variables (Table 4 and Fig. 1).

The total prevalence of $\mathrm{SCH}$ was $11.30 \%$ and was not significantly different between genders $\left(X^{2}=1.32\right.$, $p=0.63$ ) (Table 1). Furthermore, combining the population of children diagnosed with overweight and

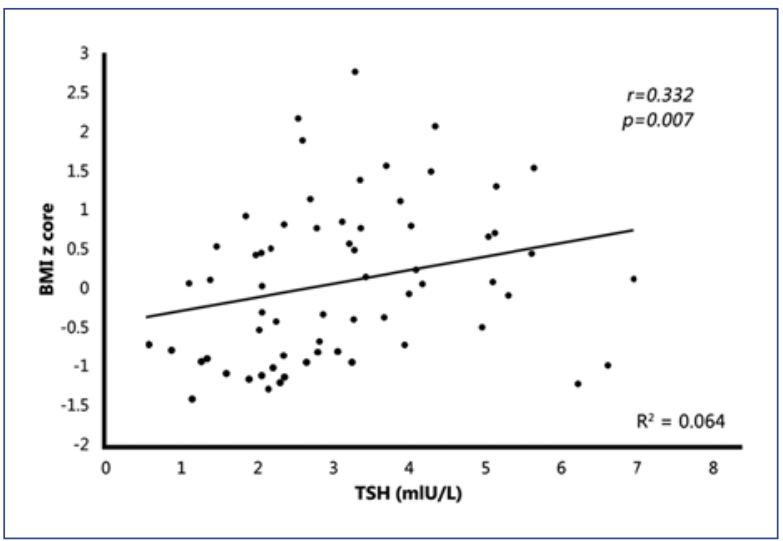

Figure 1. Correlation between body mass index (BMI) z-score and thyroid-stimulating hormone levels (TSH).

obesity in one group, the prevalence was significantly higher in comparison with normal weight children $\left(11.27 \%\right.$ vs. $\left.2.81 \%, X^{2}=6.0, p=0.05\right)$. In addition, children with abdominal obesity doubled the prevalence of $\mathrm{SCH}$ with respect to those without abdominal obesity $\left(X^{2}=5.8, p<0.05\right)$ (Fig. 2).

\section{Discussion}

The thyroid dysfunction has been associated with metabolic disorders related to obesity ${ }^{22,23}$, such as 
Table 3. Thyroid hormone levels in children stratified by nutritional status

\begin{tabular}{|c|c|c|c|c|c|}
\hline Nutritional condition & TSH (mIU/L) & $\mathrm{T}_{4}(\mathrm{nmol} / \mathrm{L})$ & $\mathrm{T}_{3}(\mathrm{nmol} / \mathrm{L})$ & $\mathrm{FT}_{4}(\mathrm{pmol} / \mathrm{L})$ & $\mathrm{T}_{3} / \mathrm{T}_{4}$ \\
\hline $\begin{array}{l}\text { BMI } \\
\text { Undernutrition } \\
\text { Normal Weight } \\
\text { Overweight } \\
\text { Obesity }\end{array}$ & $\begin{array}{c}3.53 \pm 2.09 \\
2.43 \pm 1.37 \\
3.40 \pm 1.50 \\
3.50 \pm 1.13^{*}\end{array}$ & $\begin{array}{l}63.38(27.67) \\
73.36(46.33) \\
73.36(33.46) \\
75.93(46.33)\end{array}$ & $\begin{array}{l}0.65(0.76)^{*} \\
0.93(0.38) \\
0.86(0.35) \\
0.98(0.20)\end{array}$ & $\begin{array}{l}16.19 \pm 2.27 \\
16.84 \pm 2.92 \\
16.09 \pm 3.14 \\
16.71 \pm 2.40\end{array}$ & $\begin{array}{l}0.012 \pm 0.008 \\
0.014 \pm 0.005 \\
0.014 \pm 0.005 \\
0.013 \pm 0.004\end{array}$ \\
\hline $\begin{array}{l}\text { WC } \\
\text { Non-abdominal obesity } \\
\text { Abdominal obesity }\end{array}$ & $\begin{array}{l}2.96 \pm 1.56 \\
3.45 \pm 1.20\end{array}$ & $\begin{array}{l}73.35(36.04) \\
73.36(36.36)\end{array}$ & $\begin{array}{l}0.85(0.37) \\
0.98(0.25)\end{array}$ & $\begin{array}{l}16.70 \pm 2.96 \\
16.31 \pm 2.31\end{array}$ & $\begin{array}{l}0.013 \pm 0.005 \\
0.013 \pm 0.005\end{array}$ \\
\hline $\begin{array}{l}\text { WHtR } \\
\text { Non-obesity } \\
\text { Obesity }\end{array}$ & $\begin{array}{c}2.75 \pm 1.52 \\
3.50 \pm 1.35^{*}\end{array}$ & $\begin{array}{l}69.50(38.93) \\
77.22(28.96)\end{array}$ & $\begin{array}{l}0.85(0.37) \\
0.98(0.33)\end{array}$ & $\begin{array}{l}16.43 \pm 2.77 \\
16.72 \pm 2.82\end{array}$ & $\begin{array}{l}0.013 \pm 0.006 \\
0.013 \pm 0.005\end{array}$ \\
\hline
\end{tabular}

Values are mean $\pm S D$ in data with a normal distribution (TSH and $\mathrm{FT}_{4}$ ) or median (IQR) in data with non-normal distributions $\left(\mathrm{T}_{4}\right.$ and $\left.\mathrm{T}_{3}\right)$. ${ }^{*}$ Indicates significant differences different compared to normal weight children or between non-obesity and obesity ( $p<0.05$, by ANOVA or Student's t-test).

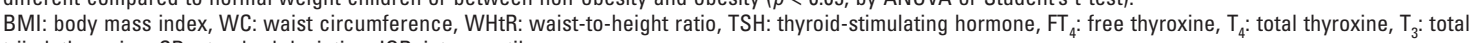
triiodothyronine. SD: standard deviation, IQR: interquartile range

Table 4. Correlation of TSH and thyroid hormone levels with nutritional status indicators.

\begin{tabular}{|c|c|c|c|c|c|c|c|c|c|c|}
\hline \multirow[t]{2}{*}{ Variables } & \multicolumn{2}{|c|}{ TSH (mIU/L) } & \multicolumn{2}{|c|}{$\mathrm{T}_{4}(\mathrm{nmol} / \mathrm{L})$} & \multicolumn{2}{|c|}{$\mathrm{T}_{3}(\mathrm{nmol} / \mathrm{L})$} & \multicolumn{2}{|c|}{$\mathrm{FT}_{4}(\mathrm{pmol} / \mathrm{L})$} & \multicolumn{2}{|c|}{$\mathrm{T}_{3} / \mathrm{T}_{4}$} \\
\hline & $\mathbf{r}$ & $\mathbf{p}$ & $\mathbf{r}$ & $\mathbf{p}$ & $\mathbf{r}$ & $\mathbf{p}$ & $\mathbf{R}$ & $\mathbf{p}$ & $\mathbf{r}$ & $\mathbf{p}$ \\
\hline Weight (kg) & 0.274 & $0.021^{*}$ & 0.159 & 0.185 & -0.106 & 0.379 & -0.038 & 0.751 & -0.062 & 0.64 \\
\hline Weight z score & 0.337 & $0.006^{*}$ & 0.194 & 0.119 & -0.088 & 0.483 & -0.046 & 0.711 & -0.184 & 0.138 \\
\hline BMI $\left(\mathrm{kg} / \mathrm{m}^{2}\right)$ & 0.313 & $0.010^{*}$ & 0.134 & 0.281 & 0.060 & 0.650 & -0.017 & 0.891 & -0.099 & 0.429 \\
\hline BMI z score & 0.332 & $0.007^{*}$ & 0.186 & 0.136 & 0.006 & 0.963 & -0.033 & 0.794 & -0.099 & 0.429 \\
\hline$W C(\mathrm{~cm})$ & 0.266 & $0.025^{*}$ & 0.089 & 0.459 & -0.049 & 0.684 & -0.026 & 0.831 & -0.104 & 0.406 \\
\hline WC Z score & 0.305 & $0.014^{*}$ & 0.154 & 0.218 & -0.010 & 0.939 & 0.003 & 0.980 & -0.158 & 0.69 \\
\hline WHtR & 0.256 & $0.031^{*}$ & 0.110 & 0.363 & -0.006 & 0.960 & -0.022 & 0.858 & -0.019 & 0.89 \\
\hline WHtR z score & 0.297 & $0.016^{*}$ & 0.159 & 0.201 & 0.053 & 0.673 & 0.025 & 0.84 & -0.480 & 0.703 \\
\hline
\end{tabular}

Data are presented as the Pearson or Spearman correlation coefficient according to their normal or non-normal distribution, respectively. ${ }^{*}$ Indicates significant correlation $(p<0.035)$.

BMI: body mass index, WC: waist circumference, WHtR: waist-to-height ratio, TSH: thyroid-stimulating hormone, $\mathrm{FT}_{4}$ : free thyroxine,

$\mathrm{T}_{4}$ : thyroxine total, $\mathrm{T}_{3}$ : triiodothyronine total

cardiovascular disorders ${ }^{24}$, dyslipidemia ${ }^{25}$, and diabetes ${ }^{22,26}$. TSH levels are responsible for TH production, and our results highlight higher TSH serum levels in our population than in other populations ${ }^{7,27}$, including data in Mexico ${ }^{10,28}$. In addition, we did not find gender differences in TSH or TH levels, similar to other reports ${ }^{29,30}$. Some factors may be responsible for the important differences in the thyroid status such as the wide range of age and pubertal development that were not considered in other studies. It is known that $\mathrm{TH}$ levels vary with age in the pediatric population ${ }^{29,30}$. Higher levels of TSH were found in pre-pubertal children, suggesting that physiological and transitory hyperthyrotropinemia may be present in the prepubertal stage, a status that is reversible on reaching pubertal development; on the basis, puberty significantly reduces the levels of TSH. A report from Lazar et al. found that high levels of TSH returned to normal after 5 years in $73.6 \%$ of children without $\mathrm{TH}$ replacement treatment when they reached pubertal development, so they propose that biological age could be an important factor to evaluate the thyroid function properly ${ }^{31}$. It is important to emphasize that patients with elevated TSH should take periodic thyroid function tests and evaluate the presence of thyroid autoantibodies. 


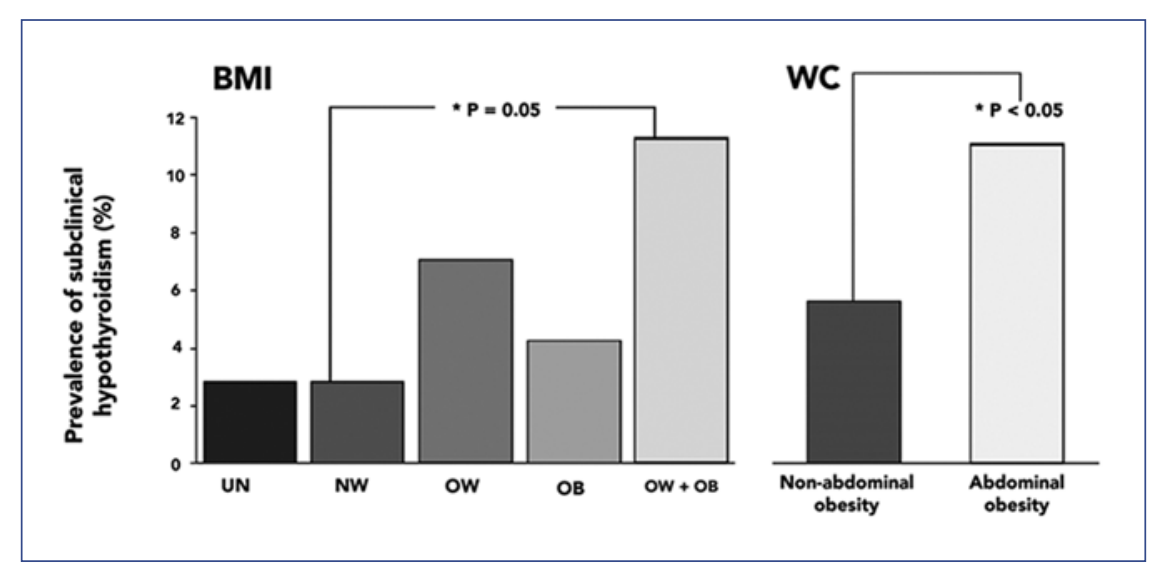

Figure 2. Data are presented as proportion of subjects with subclinical hypothyroidism relative to total population. To diagnose subclinical hypothyroidism, TSH levels $\geq 4.5 \mathrm{mIU} / \mathrm{L}$ and $<10 \mathrm{mIU} / \mathrm{L}$ with normal levels of thyroid hormones were considered. The prevalences were compared by Chi-square test $\left(X^{2}\right)$. The prevalence of HSC was greater in overweight + obesity group as well as children with abdominal obesity, compared with normal weight children.

UN: undernutrition, NW: normal weight, OW: overweight, OB: obesity, OW + OB: overweight + obesity, BMI: body mass index, WC: waist circumference.

Although there is still a controversy about the correlation between the levels of TSH and the degree of obesity, our results are comparable to those that indicate a positive and significant correlation with $\mathrm{BMI}^{4,5,32,33}$. In addition, other indicators of body fat content, such as WC and WHtR, also showed a positive correlation, reinforcing the fact that high body fat stores can be associated with high levels of TSH in children. Similar to other reports, the mean levels of TSH were significantly higher in obese subjects than in normal-weight subjects as measured by BMI $(p=0.05)$ and $\operatorname{WHtR}(p=$ $0.035)^{5,7,32}$. These results could be explained by a direct correlation between leptin levels and TSH in obese subjects $^{33}$ and other cytokines such as tumor necrosis factor-alpha, interleukin (IL)-1, and IL-6 that inhibit sodium-iodide transporter mRNA expression and iodide uptake in thyroid cells, suggesting an important role of adipose tissue in the compensatory rise in TSH levels observed in obesity ${ }^{34,35}$. In addition, it has been shown that weight loss contributes to restore the hyperthyrotropinemia of the obese subject ${ }^{6}$. Variations in the thyroid status of children with obesity may be more complex, and other mechanisms have been suggested, such as presence of thyroid autoantibodies, mutations in the THS receptor, peripheral resistance to $\mathrm{TH}$, and deficiency in the intake of dietary iodine ${ }^{34,36,37}$. Although our study did not consider variables that may explain the status of hyperthyrotropinemia associated with dietary intake of iodine, a study also conducted with Mexican population did not find any deficiencies in iodine intake of obese children with a similar age range ${ }^{28}$. In addition, TSH may directly stimulate differentiation of preadipocytes into adipocytes ${ }^{38}$ and promote greater secretion of leptin through autocrine in adipose tissue ${ }^{39}$, so that the permanence of a status of hyperthyrotropinaemia in children could promote the increase of adiposity and complications even more the weight loss. The results suggest the need to integrate more studies in a larger group to thoroughly analyze thyroid function in the Mexican population as recommended by Sánchez-Romero et al., who reported that subclinical forms of thyroid function are a health problem in Mexico that is rarely detected and that needs to be addressed to prevent the development of gross thyroid disorders and their complications ${ }^{10}$.

Moreover, we analyzed the thyroid status of a small group of children with undernutrition $(n=6)$. This condition is a nutritional problem that has declined in some countries, although it is still a public health concern. To some extent, studies of thyroid function in malnutrition are outdated, and we found that our results are very similar to those reported in children with marasmus and kwashiorkor ${ }^{40,41}$. Our undernourished group showed high values of TSH similar to obese children, although no significant differences were found when compared with the normal weight group, probably due to the small size of the sample. In addition, the levels of $\mathrm{T}_{3}$ tended to be low compared to normal weight children, without apparent changes in $\mathrm{FT}_{4}$. It is possible that lower levels of $T_{3}$ can explain an increase in circulating levels of 
TSH in undernourished children, where changes in $\mathrm{TH}$ would conserve energy through a reduction in the expenditure $^{35,36}$. The hypothesis that leptin may be the link between weight status and TSH could explain the high TSH levels in our children with obesity, but it is important to notice that other mechanisms may be involved in undernutrition. It has been proven that early malnutrition produces permanent changes in the hypothalamus-pituitary-thyroid axis with consequent low body weight, size, resting metabolic rate, and facultative thermogenesis in rats. From these observations, we hypothesized that undernutrition predisposes individuals to exhibit adult $\mathrm{SCH}^{35}$.

The effect of obesity on variations in TH levels has been controversial in several reports, and although it is difficult to establish a general trend for these variables, total $T_{4}$ levels are frequently higher, while free fractions of $T_{4}$ and $T_{3}$ are normal or only slightly higher in obese children than normal weight children ${ }^{5,6,32,42}$. Nevertheless, our results showed no variations in the levels of $\mathrm{TH}$ or in the $\mathrm{T}_{3} / \mathrm{T}_{4}$ relationship as a peripheral deiodinase activity indicator. Similar to some studies, we found that there was no significant correlation between $\mathrm{TH}$ levels and indicators of nutritional status ${ }^{5,32}$.

Regarding BMI, the prevalence of $\mathrm{SCH}$ in overweight and obese children was greater than in subjects with normal weight or undernutrition, so it is important to follow-up these children with complementary studies of thyroid function. In addition, children diagnosed with overweight according to BMI presented SCH more frequently than other nutritional conditions. In this sense, our data agree with Pacifico et al., who suggested that a compensatory mechanism, involving the increase of leptin and its action on secretory hypothalamic TRH neurons, may be more marked in overweight children as an adaptation process to increase energy expenditure and maintain body weight, and that the hyperthyrotropinemia observed in obese children may represent $\mathrm{TH}$ resistance in the pituitary gland and disturbed negative feedback ${ }^{23}$.

Although our study took place in just one geographic location and the number of participants was limited in undernutrition, our results include the comparison of thyroid full profile in different conditions of the nutritional status that can provide a more complete prospect of changes in thyroid status in Mexican children. Furthermore, it highlights the impact of pubertal development on the interpretation of thyroid function.

The present study serves as a basis for increasing the interest in the analysis of thyroid function in Mexican schoolchildren.

\section{Ethical disclosures}

The Medical Ethics Committee of the Medicine Faculty at La Salle University approved the study protocol.

\section{Funding}

This work was funded by Facultad de Ciencias Químicas at Universidad La Salle, proyect number Q-100/14.

\section{Conflicts of interest}

The authors declare that they have no conflicts of interest.

\section{References}

1. Gutiérrez JP, Rivera-Dommarco J, Shamah-Levy T, et al. Encuesta Nacional de Salud y Nutrición 2012. Resultados nacionales. Cuernavaca: Instituto Nacional de Salud Pública (MX); 2012. Available from: https:// www.goo.gl/dthogO.

2. Rodea-Montero ER, Evia-Viscarra MLE, Apolinar-Jiménez E. Waist-toheight ratio is a better anthropometric index than waist circumference and $\mathrm{BMI}$ in predicting metabolic syndrome among obese Mexican adolescents. Int J Endocrinol. 2014:2014:195407.

3. Silva JE. Thyroid hormone control of thermogenesis and energy balance. Thyroid. 1995;5:481-92.

4. Reinehr T, Isa A, de Sousa G, Dieffenbach R, Andler W. Thyroid hormones and their relation to weight status. Horm Res. 2008;70:51-7.

5. Ghergherehchi R, Hazhir N. Thyroid hormonal status among children with obesity. Ther Adv Endocrinol Metab. 2015;6:51-5.

6. Reinehr T, de Sousa G, Andler W. Hyperthyrotropinemia in obese children is reversible after weight loss and is not related to lipids. J Clin Endocrinol Metab. 2006;91:3088-91.

7. Reinher T, Andler W. Thyroid hormones before and after weight loss in obesity. Arch Dis Child. 2002;87:320-3.

8. Sone M, Osamura RY. Leptin and the pituitary. Pituitary. 2001;4:15-23.

9. Shriraam M, Sridhar M. Subclinical hypothyroidism in children. Indian Pediatr. 2014;51:889-95.

10. Sánchez-Romero LM, Barquera S, Campos I, et al. Concentraciones Séricas de Hormona Estimulante de la Tiroides (TSH) en Niños, Adolescentes y Adultos Mexicanos. Resultados de la ENSANUT 2006. México: Instituto Nacional de Salud Pública de México; 2012.

11. Ergür AT, Taner Y, Ata E, Melek E, Bakar EE, Sancak T. Neurocognitive functions in children and adolescents with subclinical hypothyroidism. $\mathrm{J}$ Clin Res Pediatr Endocrinol. 2012;4:21-4.

12. Marwaha KR, Tandon N, Desai KA, et al. The evolution of thyroid function with puberty. Clin Endocrinol (Oxf). 2012;76:899-904.

13. Brufani C, Manco M, Nobili V, Fintini D, Brbetti F, Cappa M. Thyroid function tests in obese prepubertal children: Correlations with insulin sensitivity and body fat distribution. Horm Res Paediatr. 2012;78:100-5.

14. Lopes-Machado D, Barbanti V. Maturacao esquelética e crescimento em criancas e adolescentes. Ver Bras Cineantropom. Desempenho Hum. 2007;9:12-20.

15. Hong HR, Ha CD, Kong JY, Lee SH, Song MG, Kang HS. Roles of physical activity and cardiorespiratory fitness on sex difference in insulin resistance in late elementary years. J Exerc Nutrition Biochem. 2014;18: 361-9.

16. Center for Disease Control and Prevention (CDC). BMI for Children and Teens; 2015. Available from: https://www.goo.gl/0NNEEr. [Last accessed on 2018 Feb 03]

17. Barlow $S$ and Expert Committee. Expert committee recommendations regarding the prevention, assessment, and treatment of child and adolescent overweight and obesity: Summary report. Pediatrics. 2007; 120:165-92.

18. Flores-Huerta $S$, Klünder-Klünder M, de la Cruz LR, Santos JI. Increase in body mass index and waist circumference is associated with high blood pressure in children and adolescents in Mexico City. Arch Med Res. 2009;40:208-15

19. Ashwell M, Dong-Hsieh S. Six reasons why the waist-to-height ratio is a rapid and effective global indicator for health risks of obesity and how its 
use could simplify the international public health message on obesity. Int J Food Sci Nutr. 2005;56:303-7.

20. Surks MI, Ortiz E, Daniels GH, et al. Subclinical thyroid disease: Scientific review and guidelines for diagnosis and management. JAMA. 2004;291:228-38

21. Segura SA, Jiménez JQ, Morreale de Escobar G. Enfermedades frecuentes del tiroides en la infancia. Rev Pediatr Aten Primaria. 2009; 11:S173-204.

22. Garduño-Garcia JJ, Camarillo RE, Loe OA, et al. Thyroid function is associated with insulin resistance markers in healthy adolescents with risk factors to develop diabetes. Diabetol Metab Syndr. 2015;7:16.

23. Pacifico L, Anania C, Ferraro F, Andreoli GM, Chiesa C. Thyroid function in childhood obesity and metabolic comorbidity. Clin Chim Acta. 2012;413:396-405.

24. Collet TH, Gussekloo J, Bauer DC, et al. Subclinical hyperthyroidism and the risk of coronary heart disease and mortality. Arch Intern Med. 2012;172:799-809.

25. Zhao M, Yang T, Chen L, et al. Subclinical hypothyroidism might worsen the effects of aging on serum lipid profiles: A population-based case-control study. Thyroid. 2015;25:485-93.

26. Amouzegar A, Kazemian E, Gharibzadeh S, Mehran L, Tohidi M, Azizi F. Association between thyroid hormones, thyroid antibodies and insulin resistance in euthyroid individuals: A population-based cohort. Diabetes Metab. 2015;41:480-8.

27. Grandone A, Santoro N, Coppola F, Calabro P, Perrone L, del Giudice EM Thyroid function derangement and childhood obesity: An Italian experience. BMC Endocr Disord. 2010;10:8

28. Méndez-Villa L, García-Solís P, Solís-S JC, et al. High iodine and salt intakes and obesity do not modify the thyroid function in Mexican schoolchildren. Biol Trace Elem Res. 2016;172:290-8.

29. Kapelari K, Kirchlechner C, Högler W, Schweitzer K, Virgolini I, Moncayo R. Pediatric reference intervals for thyroid hormone levels from birth to adulthood: A retrospective study. BMC Endocr Disord. 2008;8:15

30. Elmlinger MW, Kühnel W, Lambrecht HG, Ranke MB. Reference intervals from birth to adulthood for serum thyroxine $\left(T_{4}\right)$, triiodothyronine $\left(T_{3}\right)$, free $T_{3}$, free $T_{4}$, thyroxine binding globulin (TBG) and thyrotropin (TSH). Clin Chem Lab Med. 2001;39:973-9.
31. Lazar L, Frumkin RBD, Battat E, Lebenthal Y, Phillip M, Meyerovitch J. Natural history of thyroid function tests over 5 years in a large pediatric cohort. J Clin Endocrinol Metab. 2009;94:1678-82.

32. Rumińska M, Witkowska-Sędek E, Majcher A, Pyrżak B. Thyroid function in obese children and adolescents and its association with anthropometric and metabolic parameters. Adv Exp Med Biol. 2016;912:33-41.

33. lacobellis G, Ribaudo MC, Zappaterreno A, lannucci CV, Leonetti F. Relationship of thyroid function with body mass index, leptin, insulin and adiponectin in euthyroid obese women. Clin Endocrinol (Oxf). 2005;62:487-91.

34. Longhi S, Radetti G. Thyroid function and obesity. J Clin Res Pediatr Endocrinol. 2013;5:40-4

35. Ayala-Moreno R, Racotta R, Anguiano B, Aceves C, Quevedo L. Perinatal undernutrition programmes thyroid function in the adult rat offspring. Br J Nutr. 2014;111:757-65.

36. Bhowmick SK, Dasari G, Levens KL, Rettig KR. The prevalence of elevated serum thyroid stimulating hormone in childhood/adolesdcent obesity and of autoimmune thyroid diseases in a subgroup. J Natl Med Assoc. 2007;99:773-6.

37. Witkowska-Sedek E, Kucharska A, Ruminska M, Pyrzak B. Thyroid dysfunction in obese and overweight children. Endrokrynol Pol. 2017;68:54-60.

38. Draman MS, Stechman M, Scott-Coombes D, Dayan CM, Rees DA, Ludgate $M$, Zhang $\mathrm{L}$. The role of thyrotropin receptor activation in adipogenesis and modulation of fat phenotype. Front Endocrinol (Lausanne). 2017;8:83.

39. Menendez C, Baldelli R, Camiña JP, et al. TSH stimulates leptin secretion by a direct effect on adipocytes. J Endocrinol. 2003;76:7-12.

40. Orbak Z, Akin Y, Varoğlu E, Tan H. Serum thyroid hormone and thyroid gland weight measurements in protein-energy malnutrition. J Pediatr Endocrinol Metab. 1998;11:719-24.

41. Sarne D. Effects of the Environment, Chemicals and Drugs on Thyroid Function. In: De Groot LJ, Beck-Peccoz P, Chrousos G, et al., editors. Comprehensive Free On Line Endocrinology Book. South Darthmouth: Endotext; 2016. Available from: https://www.goo.gl/8gmeJo.

42. Reinehr T. Thyroid function in the nutritionally obese child and adolescent. Curr Opin Pediatr. 2011;23:415-20. 